\title{
Eastern surveillance, Western malaise, and South Korea's COVID-19 response: oligarchic power in Hell Joseon
}

\author{
George Baca ${ }^{1}$
}

Published online: 24 August 2020

(C) Springer Nature B.V. 2020

\begin{abstract}
With COVID-19, powerful political and economic forces have magnified their power and expanded inequality. Many critical scholars have celebrated how South Korean authorities have contained the virus in ways that ignore power relations. The government coordinated its pandemic response by expanding its formidable surveillance technologies for tracing, tracking, and mining every activity of ordinary citizens. State managers produced powerful images of the government, in Confucian fashion, protecting the public from a dangerous threat. I will connect these performances of power with an examination of how authorities harnessed its pandemic response to private capital. South Korea's reaction to COVID-19 does represent a positive alternative to the dominant form of oligarchic rule that prevails in Euro-American societies. The governing elite deployed state power in ways that used this conjuncture to continue previous patterns of domination that have continuously expanded surveillance, extending techniques for the extraction of vital data for commercial and political purposes. Rather than celebrate the South Korean authorities, we should analyze how COVID-19 response has deepened South Korean society's social contradictions.
\end{abstract}

In a recent commentary, Göran Therborn encourages social scientists and critical scholars to use the COVID-19 to refine and deepen our understanding of political power and the structures that socially reproduce inequality. Indeed, central banks and national governments have used the threat in ways that have made COVID-19 "a magnifying force" that strengthens preexisting structures of political and economic power (Therborn 2020). In the USA, these power plays have been crude, shortsighted money grabs that dangerously expand disparity. In late March, the US Congress devised the Coronavirus Aid, Relief, and Economic Security Act (CARES Act) to divert half of trillion dollars to the largest corporations. As Robert Brenner points out, the government credited $\$ 454$ billion to the Fed as a cushion to cover potential losses following the economy's shutdown. The Federal Reserve further leveraged Congress's

George Baca

baca.george@gmail.com

1 Graduate School of International Studies, Dong-A University, Busan, South Korea 
provision by ten, to four and a half trillion dollars (Brenner 2020: 7). In a textbook case of what Naomi Klein calls "disaster capitalism," with bi-partisan support, corporations exploited the crisis to receive bailouts and regulatory rollbacks for nothing in return (Klein 2020).

Against this image of plundering disaster capitalists running amok in the USA, many leftists have come to see the South Korean elite in a fanciful manner. A wide array of political interests - running the gamut of "left" and "right"- have contributed to an image of a popular "resistance" to Donald Trump. These varied actors have applauded the South Korean authorities' decisive use of governmental power to contain the virus. This rush to celebrate oligarchic dominance in South Korea is worrisome. Such a position requires willful ignorance of how the South Korean pandemic response has contributed to corporate power and resulted in magnifying corporate and state power in troubling ways. Presenting South Korean authorities and corporations' actions as noble and socially responsible requires that we disconnect the government's pandemic strategies from broader modes of dominance. To be sure, the South Korean authorities took the pandemic seriously. Compared with the CARES ACT's corporate smash and grab, the South Korean powers look self-sacrificing. Unlike their counterparts in the West, they had an acute understanding that an epidemic in China was likely to travel the circuits of global markets and raise the threat of a global pandemic. Nevertheless, we should critically analyze the government's narrative of protecting the common good. I will examine how the government coordinated its pandemic response in ways that have expanded its already formidable technologies for tracing, tracking, and mining activiest of ordinary citizens. State managers successfully orchestrated power in ways that produced powerful images of the government, in Confucian fashion, protecting the public from peril. I will connect these performances of power with an examination of the political and economic mechanics that harnessed the COVID response to state policies that preceded the pandemic.

\section{Hell Joseon}

As I write, in mid-July, COVID-19 is spiraling out of control in the USA. The daily average of new cases hover over sixty thousand. Simultaneously, more than a thousand Americans needlessly die each day primarily because of the Trump Administration's incompetence and corruption. With the virus' deadly resurgence in the USA, some leftist critics praise South Korea's pandemic response in ways that reduce social analysis to a yearning for the return of a capable capitalist state. Indeed, as managers of a highly financialized economy, South Korean authorities have outperformed their counterparts in Western Europe and the USA. They systematically instituted testing, contact tracing, and presented a powerful public message that has resonated with ordinary citizens.

Though the Korean authorities used great acumen in handling the virus, nothing progressive has come from these interventions. Governmental and corporate leaders came together to successfully defend the state, stabilize society, and protect the economy. Over the past two decades, South Korean industrialists - much like corporations in the West-have exported productive capital to Southeast Asia and China. Chaebol firms like Samsung and Hyundai have enjoyed record profits while the domestic economy has steadily contracted and wages have stagnated. Rising economic disparity has resulted in a growing alienation as many Koreans have lost hope in having a stable and productive life and see emigration to the USA as their most viable option. After years of suffering from a hyper-competitive education system, many younger generations identify themselves as "dirt spoons," a metaphor that 
contrasts their fortunes with wealthy "gold spoons" who dominate the country. Estranged South Koreans foresee a future of low-paying jobs and staggering debt, which leads them to increasingly abandon conventional ideals of marriage, children, homeownership, and stable careers. Instead, they view South Korea as a living hell, often termed "Hell Joseon," which was portrayed to global audiences through the academy award-winning film, Parasite. Indeed, the country's income inequality bodes poorly for most Koreans as the top $1 \%$ owns more than $25 \%$ of wealth, while the bottom $50 \%$ holds merely $2 \%$.

\section{Constructing the pandemic response}

When Korean authorities learned of the coronavirus outbreak in Wuhan in January, they understood that such an epidemic could imperil the country's increasingly fragile social hierarchy. In an arresting contrast to lackadaisical and disjointed responses in Western Europe and the USA, South Korean authorities and private business swiftly joined forces to build ramparts to defend against the virus. Before the authorities confirmed its first case, the country's leading applied scientists had created test kits for COVID-19. The Korea Centers for Disease Control and Prevention (KCDC) quickly incorporated these new products into the national pandemic response. These clear-sighted actions stemmed from the way that the government had gradually developed a pandemic emergency response plan over the previous two decades combatting SARs, H1N1, Swine Flu, and MERS. Crucial to the COVID response was the way the government established new laws amid the MERS outbreak in 2015. State agencies, foreseeing future epidemics, formed closer relationships with biotech firms to establish a national approach to disease control. Codified in a "pandemic playbook," the authorities instituted protocols and a legal framework that allowed the government to mobilize biotech firms quickly, bypassing regulations to ensure rapid production of medical devices and services.

On January 20, 4 days after South Korean biotech firms had made a COVID-19 test, authorities announced its first case. In line with the western narrative of East Asian efficiency, South Korean authorities embarked upon a wave of testing. Rather than wait for a spike in cases, authorities carried out a plan that tested thousands of asymptomatic people. Moreover, they enlisted surveillance companies - using CCTV, credit card transactions, and telephone companies to track and trace each confirmed. The efficacy of mass testing seemed successful. After a month of systematic testing, South Korea registered merely thirty confirmed cases and zero fatalities. The feeling of victory was fleeting, though.

Though health administrators had meticulously recorded and enclosed the first thirty patients, something went wrong with the thirty-first confirmed case. An infected 61-year-old woman glided beneath the radar long enough to unleash a torrent of new infections. On February 16, she carried the virus into the Shincheonji Church of Jesus in Daegu. She joined one thousand fellow parishioners in worship as they followed each of the pastor's declarations with "amen," producing ideal conditions for the virus to spread. Once identified, after a minor car crash, tracking and tracing efforts led health officials to suspect that the stigmatized Christian sect was harboring a multitude of infected people. As the government zoomed in, the KCDC attributed the sudden jump of seventy cases on March 20 to patient number thirtyone, who became infamous in South Korea and globally as the "super-spreader" who threw the country into a tailspin, contributing to the biggest coronavirus outbreak outside of China, at the time. 
Law enforcement raided the Church's headquarters and recovered information that allowed them to eventually track and trace more than two hundred thousand members. As health officials focused on the Church, the country's COVID numbers surged past two thousand by the end of the month and doubled again during the first few days of March. Church members comprised more than sixty percent of South Korea's cases at that time, which fueled an antiShincheonji movement resulting in a petition, with more than seven hundred and fifty thousand signatures that called for its disbanding. Moreover, the Seoul government prepared a lawsuit against the Shincheonji Church's founding member and senior leadership for murder and violating the Infection Disease Control and Prevention Act. ${ }^{1}$

With a clear-cut villain and an example of dangerous behavior, the government and media used the Shincheonji calamity to construct a powerful image of a crisis. The media panic cleared the streets over the weekend. When people started coming back into public spaces, they did so wearing masks. Moreover, the government overhauled its repertoire of proactive measures. The first line of defense was the massive expansion of testing. Health officials would open up more than six hundred testing centers as they designed the new infrastructure to test as many people as possible. The proliferation of testing became world-famous as the government set up drive-through testing facilities. Patients would drive up to healthcare workers, dressed head-to-toe in protective gear. Within minutes, they would send the sample off to a nearby lab, which would text the results within hours. In addition, walk-in centers popped up everywhere. Patients would enter a chamber that resembles a phone booth, from which healthcare workers would collect a sample. In these various ways, tests became readily available and affordable to almost everyone. By mid-March, 3 weeks after the Shincheonji incident, the national health system tested more than twenty thousand patients a day, and they had "flattened the curve."

Testing tells part of the story. The successful use of testing depended upon the vast use of monitoring and surveillance. Patient thirty-one inspired officials to ramp up its efforts to "track and trace." Authorities used the various players in these fields of data collection. Various government agencies gobbled up information from credit card transactions, CCTV footage, phone towers, mobile apps, and "smart city" surveillance systems. After processing data, the government would send out "emergency alerts" through text message. The texts notified residents of confirmed cases in their cities, often detailing highly personal information about where they had been. During the height of the epidemic, my phone would continually beepinforming me of each patient who tested positive for coronavirus in my area of the city. Some of the details were shocking, as the messages would mention previous criminal charges, or that a person was had visited a "love motel" or risqué bars - in some cases inciting accusations of extramarital affairs. Moreover, the government made all of this information available on the Ministry of Health and Welfare websites. Though these notifications did not provide names and addresses, they gave enough data that led to people speculating about others. The growing sense of fear that someone could be identified as not conforming to the strict protocols or be accused of carrying the disease contributed to the widespread wearing of masks. A bevy of mobile apps would follow. Residents could learn which buildings, businesses, and neighborhoods contained infected people.

\footnotetext{
${ }^{1}$ On July 31, 2020, authorities arrested Shincheonji's leader on charges of obstructed the government efforts to control the virus and for embezzling over 5.5 billion Korean Won ( $\$ 4.7$ million). Public health authorities cred the Church with more than 5200 infections, $36 \%$ of the country's cases.
} 
Before the pandemic, Korean tech firms had developed a litany of mobile apps, social media platforms, and "smart technologies" that continuously monitor vital data. Shoshana Zuboff refers to this sector of the economy as "surveillance capitalism," which produces surpluses through the extraction of data from the customers of telephone companies, internet services, mobile apps, and social media. She argues that this is a distinct form of capitalist extraction whereby capitalists "claim human experience as raw material to create behavior data. As such, firms declare data collected from users of their services as a 'proprietary behavior surplus,' which they then feed into an 'advanced manufacturing process' known as 'machine intelligence' to fabricate products that anticipate what you will do now, soon, and later." Ultimately, surveillance capitalists "seek to acquire predictive sources of behavioral surplus that can shape, coax, and herd behavior to specific political outcomes" (2019: 8).

Over the previous decade, South Korean tech companies have expanded such capabilities in frightening ways. Sophisticated cameras blanket the country. Many of these devices are equipped with advanced facial recognition and artificial intelligence features that can observe and evaluate public behavior. Extensive surveillance has been at the center of new forms of urban governance in South Korea that relyon metadata surveillance strategies euphemized as "smart city" technology. These systems integrate surveillance with urban infrastructure, providing tech companies with immense power. Proponents celebrate smart cities for tailoring technology to make effective and positive changes in everyday lives, like renovating urban planning and managing cities' core functions. In this way, city administrators deploy data and digital technology to increase what they claim is the government's efficiency, infrastructural improvement, and overall "resilience".

These urban structures outfitted with tracking and tracing technologies have continued to chip away at suspicion as part of the larger effort to convince citizens to sacrifice personal privacy. South Korean officials and the media have used COVID-19 to expand the campaign to persuade citizens that the government's encroachment into private life through monitoring and surveillance is part of progress. Moreover, through the fear of viruses, tech companies and governments have used biology to accelerate the digitization of the world. Over the past 20 years, infections - in the form of epidemics and pandemics - have established the perfect conditions for surveillance capitalists to expand the infrastructure for digitizing social life and the economy, making ordinary citizens increasingly dependence on devices and mobile apps (Carrión 2020). In this way, we can see that South Korea's pandemic model is not something to replicate. Instead, it displays the most troubling features of surveillance-based innovations in the economy and government. South Korea has used COVID-19 to inject massive amounts of resources into big data industries, providing an enormous boost to algorithmic intelligence (Carrión 2020). COVID-19 has become a showcase for government agencies and private capital to present their capabilities and control over society as a positive force in organizing and regulating society.

South Korean officials have waged a campaign through relentless public messaging that urges residents to seek testing, wear facemasks, and implement social distancing. In many ways, the constant bombardment of public messages creates the feeling that COVID-19 represents a war-like emergency. Authorities cultivated a compelling image of the threat to compel conformity to government directives in the name of the nation's collective interest. Having established vivid pictures of an emergency, the government has gained support for its use of surveillance. Unfortunately, some commentators have contributed to the celebration of South Korea's approach by replacing the question of the digitization of state power and the political economy, with the topic of Confucianism. They credit Confucian traditions as a 
source of East Asian success compared with the West (See Han 2020; Murphy 2020). For Taggart Murphy, Confucianism has established "a willingness" for the public "to trust experts." He argues that "education and training are revered in the East," noting that there is "little counterpart to the disdain for expertise that characterizes so much of British and American political culture. A presidential candidate gaining power by deliberately fomenting popular resentment against learning and science - as happened in the United States - is simply unimaginable in today's East and Southeast Asia" (Murphy 2020: 61). Unfortunately, this culturalist reading presumes that these state managers and health officials have responded to an ideal public good. This type of argument short-circuits critical analysis of the ways state managers have fashioned the "public good" in ways that reinforce the interests of financial and surveillance capitalists. Official messaging deployed science and epidemiological expertise to present the government as protecting the general public, a task that required citizens to internalize a sense of responsibility to conform to the government's expectations. Rather than representing Confucian culture, the elite-focused on social reproduction of capitalist relations - has mobilized Confucian ideals to build a sense of trust. They made the argument that combatting the virus required digital surveillance. In this context, the elite navigated class conflicts by presenting big data as the key to defending the nation against the pandemic.

\section{Conclusions: confessions of a bourgeois academic}

The striking feature of my pandemic experience has been the realization that living in South Korea, under strict surveillance, is my best possible option. One of my colleagues with whom I taught with in the USA, who also took a job in South Korea, raves about how happy he is to be in South Korea during the pandemic. In the most crucial ways, COVID-19 has not interrupted my life in any meaningful way. Over the past 5 months, I have continued my professional obligations of writing, reading, and teaching. As South Korea never went into lockdown, my semester of on-line teaching was a pleasure. I was able to leave my apartment more than once a day - which often included nice walks on the beach. By late March, meeting friends at coffee shops or restaurants became normal. Moreover, the government's efficient management meant that I never experienced food shortages nor bizarre runs on toilet paper or hand sanitizer. Therefore, it would be easy for me to speak glowingly about how the South Korean authorities handled the pandemic and join the anti-Trump chorus. However, it would be disingenuous to equate my bourgeois bliss, and policies that maintain it, with a mythical "99\%." Policies that support the last vestiges of middle-class privileges have little to promise the working classes, let alone the growing sub-proletariat who make up the bulk of the mythic abstraction that faces off against the " $1 \%$." Critical scholars. must acknowledge that our lot as privileged members of industrial societies is cast with capital. To do, or say, anything worthwhile for the larger "crisis" that is destroying the planet means that we must separate our immediate interests from a truly transformative project. And this partly explains why the proliferation of surveillance in South Korea does not seem to bother so many liberals and progressives.

In this light, South Korea's response to COVID-19 does not represent a positive alternative to the dominant form of oligarchic rule that prevails in Euro-American societies. Instead, it provides a systemic deployment of governmental power that is consonant with corporate dominance of politics in the West. South Korean authorities have deployed state power in ways that use this conjuncture to continue previous patterns of domination that have continuously expanded power into the most intimate details of ordinary citizens. The pandemic 
response has built on and extended techniques for the extraction of data for producing surpluses. In this way, South Korean authorities' response to the COVID pandemic provides insights for the oligarchs in the USA, Western Europe, and the Global South. South Korean authorities, not letting the crisis go to waste, have used the threat of a deadly virus to accelerate digitization of governance. Rather than celebrate the South Korean authorities, we should analyze how COVID-19 response has deepened South Korean society's social contradictions. South Korean state managers and corporate leaders have shown that the virus has not established the conditions for serious reform. Instead, they have used the virus to further split up and individualize citizens in ways that do not establish a collective basis for social change. Instead, they have mobilized a collective sense of being to reproduce the social conditions that so many South Koreans find abhorrent and hellish.

Acknowledgments I would like to thank Victor Braitberg, Robert Beachy, George Khoury, and Anthony Marcus for the helpful comments that improved this paper.

Funding information This study was supported by research funds from Dong-A University.

\section{References}

Brenner, Robert. 2020. Escalating plunder. New Left Review.

Carrion, Jorge. 2020. La biología está acelerando la digitalización del mundo, New York Times, 29_March_2020.

Han, B. C. 2020. La emergencia viral y el mundo de mañana. Byung-Chul Han, el filósofo surcoreano que piensa desde Berlín. El País, 21_March_2020.

Klein, Naomi. 2020. Under cover of mass death, Andrew Cuomo calls in the billionaires to build a high-tech dystopia. The Intercept. 9_May_2020.

Murphy, R. Taggart. 2020. East and West: Geocultures and the coronavirus. New Left Review 122: 58-64.

Therborn, Goran. 2020. Opus magnum: How the pandemic is changing the world, thesis eleven: Critical theory and historical sociology.

Publisher's note Springer Nature remains neutral with regard to jurisdictional claims in published maps and institutional affiliations. 